\title{
Beheersing van de Nederlandse taal onder recente migranten uit nieuwe EU-lidstaten en traditionele migratielanden
}

\author{
Mérove Gijsberts \& Marcel Lubbers
}

\begin{abstract}
Sinds 2004 heeft de migratie uit Polen een vlucht genomen en sinds 2007 is de migratie uit Bulgarije naar Nederland flink hoger dan daarvoor. In deze bijdrage stellen we de vraag in hoeverre migranten uit deze nieuwe EU-landen die nog maar kort in Nederland zijn, de Nederlandse taal vaardig zijn. Daartoe vergelijken we deze groep met recente migranten uit de traditionele migratielanden Turkije en Marokko. De bevindingen bevestigen eerder onderzoek dat integratie in Nederland gepaard gaat met een betere beheersing van het Nederlands. Tevens laat de studie zien dat beheersing van een derde taal (Engels, Duits of Frans) gepaard gaat met een betere beheersing van het Nederlands.
\end{abstract}

\section{Inleiding}

De wetgeving over wie naar Nederland mag komen is de laatste decennia stevig veranderd. De regels voor migratie zijn beduidend restrictiever geworden. Anderzijds zijn er door de uitbreiding van de Europese Unie voor inwoners van een groter aantal landen minder restricties. Polen en Bulgaren migreren nu bijvoorbeeld makkelijker naar Nederland dan voorheen. Sinds de uitbreiding van de Europese Unie van 15 naar 25, en later naar 27 landen, zijn de migratiepatronen in Nederland dan ook aanzienlijk veranderd. Sinds 2005 komen er van alle migranten naar Nederland jaarlijks de meeste uit Polen en sinds 2007 zijn migranten uit Bulgarije de derde groep. De migratie van Marokkanen liep juist terug (zie figuur 1). Economisch gemotiveerde migratie uit landen buiten de Europese Unie van mensen zonder vermogen is vrijwel onmogelijk gemaakt. Migratie uit deze landen bestaat voornamelijk uit familiegerelateerde migratie. De economische motieven overheersen onder de Polen en Bulgaren, zoals uit een recent rapport van het SCP blijkt (Gijsberts en Lubbers 2013). De aandacht in politiek en media voor groepen lijkt gelijke tred te houden met de migratiecijfers. De laatste jaren is de aandacht verschoven van integratie van tweede generatie Turken en Marokkanen naar cumulatie van problemen rond migranten uit Midden- en Oost-Europese landen (de zogenoemde MOE-landen). Vooral naarmate het tijdstip naderde waarop Bulgaren en Roemenen zich zonder tewerkstellingsvergunning op de Nederlandse arbeidsmarkt mochten begeven (per 1 januari 2014), nam de aandacht in media en politiek exponentieel toe. Men toonde zich met name bezorgd over de te verwachten migratiestromen na 1 januari 2014, maar ook over de inpassing van nieuwe migranten uit Oost-Europa. De Nederlandse overheid ontbeert een instrument om migranten uit de MOE-landen te laten inburgeren zoals ze dat 
doet bij niet-westerse migranten (met uitzondering van Turken ${ }^{1}$ ). Toch heeft de overheid als doel dat alle nieuwe migranten de Nederlandse taal vaardig zijn en kennis hebben van de Nederlandse samenleving. De vraag die in dit artikel centraal staat, is in hoeverre recente migranten vlak na migratie de Nederlandse taal al beheersen.

Onder de nieuwe migranten uit Midden- en Oost-Europa is vooralsnog betrekkelijk weinig onderzoek verricht (voor een overzicht van het wel verrichte onderzoek zie Snel et al. 2013). Dat geldt bovenal voor de Bulgaren en Roemenen. Engbersen en collega's hebben in diverse Nederlandse steden en dorpen onderzoek gedaan naar deze groep. Deze groep bestaat voor een groot deel uit tijdelijke arbeidskrachten die zich niet als formele migrant hebben geregistreerd, dat wil zeggen dat zij zich niet hebben laten registeren in de Gemeentelijke Basisadministratie (GBA). Uit het onderzoek komt onder andere naar voren dat de positie van Bulgaren in Nederland ongunstig is, meer dan die van de Polen. Het blijkt een relatief laag opgeleide groep met problemen op het terrein van bijvoorbeeld huisvesting, illegaliteit en werkloosheid (zie Engbersen et al. 2011). Het SCP heeft onderzoek gedaan onder Polen die maximaal vijf jaar in Nederland geregistreerd zijn (Dagevos 2011). Alleen degenen die van plan zijn langer dan vier maanden in Nederland te verblijven zijn verplicht zich in te schrijven in de GBA. Dit betekent dat in het SCP-onderzoek Polen met een langdurig verblijfsperspectief sterker in het onderzoek zijn vertegenwoordigd dan in het onderzoek van Engbersen et al. Uit het onderzoek is dit ook duidelijk gebleken. Er is sprake van een fors aandeel dat van plan is in Nederland te blijven en ook veelal al met partner en/of kinderen in Nederland woont. Meer recentelijk is onderzoek gedaan naar recent gemigreerde Polen en Bulgaren, eveneens in de GBA ingeschreven (Gijsberts en Lubbers 2013). Hier kwam ook naar voren dat een aanzienlijk deel van de groep een langdurig verblijfsperspectief voor ogen heeft. Dit bleek meer het geval onder de Polen dan onder de Bulgaren. Met betrekking tot de arbeidsmarkt bleek er reden tot zorg. Het onderzoek liet zien dat met name onder Bulgaren slechts weinigen een baan hebben. De Polen, die veelal wel werken, doen dat vaak in tijdelijke banen aan de onderkant van de arbeidsmarkt in sectoren die gevoelig zijn voor de conjunctuur (zie ook Lubbers en Gijsberts 2013). Ook bleek de beheersing van de Nederlandse taal een probleem voor deze nog niet zo lang in Nederland woonachtige Polen en Bulgaren.

Toch weten we ook weinig over migranten uit Turkije en Marokko die recentelijk naar Nederland zijn gemigreerd. Al het voorgaande onderzoek richtte zich op een dwarsdoorsnede van de Turkse en Marokkaanse populatie in Nederland, met recentelijk meer aandacht voor de tweede generatie. In deze bijdrage maken we gebruik van een unieke databron waarin gegevens zijn verzameld onder Polen en Bulgaren, maar ook onder Turken en Marokkanen die zich als nieuwe inwoner

1 Volgens de zogenaamde associatieverdragen tussen de Europese Unie en Turkije moeten Turken naar Europa kunnen migreren zonder dat hun dergelijke integratievoorwaarden worden opgelegd. De associatieverdragen hebben als doel de arbeidsmarkttoetreding van Turken tot de EU te vergemakkelijken, en om Turken die zijn gemigreerd naar de EU juridisch gelijk te behandelen als EU-ingezetenen. De rechter sprak in 2011 uit dat Turken geen inburgeringscursus hoeven te doen. 


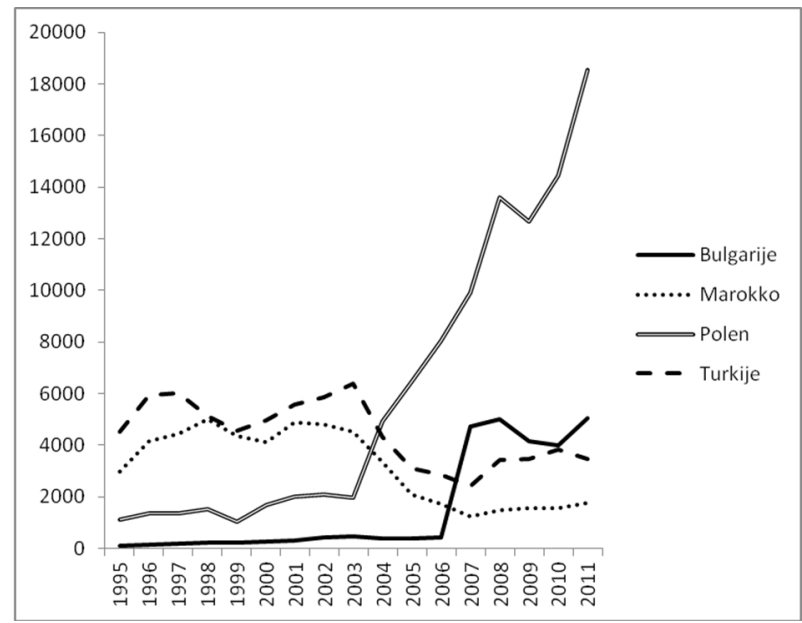

Figuur 1 Aantal migranten per jaar naar Nederland, 1995-2011 (bron: CBS Statline)

van Nederland hebben ingeschreven in 2009 of 2010. Zij hebben allen binnen anderhalf jaar na inschrijving aan een interview deelgenomen.

In deze bijdrage onderzoeken we in hoeverre nieuwe migranten uit Polen en Bulgarije en uit Turkije en Marokko de Nederlandse taal al vaardig zijn en in hoeverre we variatie binnen deze groepen in hun taalbeheersing kunnen verklaren.

\section{Theorie en hypothesen}

Drijfueren en mogelijkheden

Eerder onderzoek naar taalverwerving onder migranten onderscheidt drijfveren om de taal te leren en mogelijkheden om de taal te leren (Carliner 2000; Chiswick en Miller 2001; Van Tubergen en Kalmijn 2005, 2009). De drijfveren zijn gestoeld op kosten-batenafwegingen. Vanuit het menselijk-kapitaal-argument zullen investeringen in taal, net als in opleiding, economisch rendement opleveren. Derhalve is vaak als argument gegeven dat migratiemotieven van belang zijn voor het verklaren van de taalvaardigheid: migranten met economische motieven zullen een sterkere drijfveer hebben om de taal te leren (Chiswick en Miller 2001). Deze hypothese werd echter verworpen in de studie van Van Tubergen en Kalmijn onder Turken en Marokkanen in Nederland. De drijfveren om de taal te leren bleken sterker samen te hangen met de verwachting voor langere tijd in Nederland te verblijven. Zeker voor migranten die nog niet lang geleden naar Nederland zijn verhuisd, lijkt de intentie om langer in Nederland te blijven een belangrijke voorwaarde om de taal te leren. In navolging hiervan verwachten we dat de intentie om in Nederland te blijven, een betere beheersing van het Nederlands tot gevolg heeft. 
De mogelijkheden om de taal te leren worden veelal gekoppeld aan integratie van migranten op andere terreinen. Een eerste bijna vanzelfsprekende verwachting is dat langere blootstelling (het aantal maanden in Nederland) aan de Nederlandse samenleving het spreken van de Nederlandse taal zal bevorderen (Driessen 2004), omdat men langer in de gelegenheid is geweest om zich de Nederlandse taal eigen te maken. Ook kunnen we verwachten dat migranten die al voor hun migratie een periode langer dan vier weken in Nederland waren en die mensen in Nederland kenden voor migratie de Nederlandse taal beter beheersen.

Het is herhaaldelijk gevonden dat integratie op een bepaald terrein van invloed is op integratie van migranten op andere terreinen - ook al zijn er studies die laten zien dat dit niet als een vanzelfsprekendheid moet worden aangenomen, met voorbeelden die aangeven dat culturele integratie niet gekoppeld is aan economische integratie (Tolsma, Lubbers en Gijsberts 2012). Beter ook is het om hier te spreken van associaties, omdat nauwelijks is aangetoond dat integratie op het ene terrein voorafgaat aan integratie op een ander terrein. Hoewel migranten die een paar maanden in Nederland zijn eerder een baan zullen vinden wanneer zij het Nederlands vaardig zijn, is de verwachting ook dat werkende migranten het Nederlands sneller zullen leren, omdat zij vaker in de mogelijkheid zijn om Nederlands te spreken (bijv. Driessen 2004). We verwachten dat migranten met werk het Nederlands meer vaardig zijn dan migranten zonder werk.

\section{Sociale integratie}

Ook voor sociale integratie geldt dat de wederkerigheid niet goed te onderzoeken is zonder longitudinale gegevens. Het enigszins beheersen van de Nederlandse taal lijkt een belangrijke voorwaarde voor het aangaan van contacten met Nederlanders, terwijl het hebben van contacten met Nederlanders ook de Nederlandse taal doet verbeteren. Sterke integratie in de eigen groep is naar verwachting een barrière voor het leren van de Nederlandse taal (zie Chiswick en Miller 1996; Jasso en Rozenzweig 1990; Van Tubergen en Kalmijn 2009). Hoe meer contacten migranten hebben met Nederlanders, des te beter zijn zij de Nederlandse taal vaardig. Anderzijds verwachten we dat naarmate migranten meer contacten hebben binnen de eigen groep, zij de Nederlandse taal slechter vaardig zijn.

Gelegenheids- en investeringsfactoren kunnen niet alleen op individueel niveau doorwerken, maar ook op een hoger aggregatieniveau. De overheersende visie dat etnische concentratie de integratie belemmert, is er min of meer impliciet op gebaseerd en heeft in dat opzicht een zowel 'onvrijwillige' als 'vrijwillige' component. In het eerste geval is de veronderstelling dat etnische concentratie negatief uitwerkt op de beheersing van het Nederlands, omdat de gelegenheid tot contact met de autochtone bevolking afneemt naarmate er meer migranten of zelfs groepsgenoten in een wijk wonen. In concentratiebuurten zijn de ontmoetingskansen tussen autochtonen en allochtonen immers lager. Aan de andere kant is ook de noodzaak te investeren in de Nederlandse taal kleiner als er meer leden van de eigen etnische groep in de buurt wonen. Je kunt je dan immers ook in de eigen taal redden (zie Gijsberts en Dagevos 2007; Vervoort 2011). De veronderstelling dat etnische concentratie het leren van het Nederlands zal afremmen, is dus vooral gebaseerd op de veronderstelling dat als gevolg van deze concentratie con- 
tacten met de autochtone bevolking worden belemmerd. In de literatuur spreekt men van de taalcontactthese (Driessen 2004) of isolatiethese (Van der Laan Bouma-Doff 2005). We veronderstellen dus dat de aanwezigheid van groepsgenoten uit de eigen etnische groep in de woonomgeving een belemmerende rol speelt in het leren van het Nederlands.

\section{Hulpbronnen}

Naarmate men meer opleiding heeft genoten, zou het voor migranten eenvoudiger kunnen zijn om de Nederlandse taal te leren. Hier spelen hulpbronnentheorieën een rol (Chiswick en Miller 2001). Deze theorieën gaan ervan uit dat naarmate migranten over meer menselijk kapitaal beschikken, zij de taal van het bestemmingsland veel sneller en beter zullen leren. Mensen met een hogere opleiding zullen dus minder moeite hebben met het leren van het Nederlands. Dat deze relatie bestaat, is al in veel eerder onderzoek vastgesteld (Driessen 2004; Van Tubergen en Kalmijn 2002).

In eerder onderzoek is naar voren gekomen dat de moedertaal een belangrijke rol speelt bij de verwerving van de taal van het bestemmingsland (bijv. Chiswick en Miller 2001). Bestemmingstalen die in linguïstisch opzicht meer verwant zijn aan de moedertaal zijn gemakkelijker te leren, omdat ze daarmee meer gemeenschappelijk hebben dan talen die verder verwijderd zijn. Ook in Nederlands onderzoek is deze hypothese onderzocht (bijv. Van Tubergen en Kalmijn 2005; Kooistra et al. 2008; Van der Slik 2009). In het huidige onderzoek is het echter vanwege het lage aantal herkomstlanden niet mogelijk hier nader op in te gaan. De enige opmerking die we hierover maken, is dat het Pools en Bulgaars als Slavische talen relatief verwant zijn aan de Nederlands taal omdat ze tot dezelfde Indo-Europese taalfamilie behoren, terwijl de Turkse en Marokkaanse (zowel Arabisch als Berbers) talen tot andere taalfamilies behoren.

\section{Investeringen in de Nederlandse taal}

Een belangrijke factor bij het verwerven van een tweede taal, die tot nu toe onbesproken is gebleven, is de mate waarin men zijn of haar best doet de taal van het bestemmingsland te leren. Migranten die investeren in het leren van de taal, of dit nu gaat via taalcursussen, zelfstudie of door de Nederlandse media te volgen, zullen naar verwachting een betere beheersing van de bestemmingstaal hebben, dan zij die geen moeite doen. Het kan daarbij zowel gaan om investeringen die men al pleegde voor men naar Nederland kwam, als om investeringen die pas na aankomst in Nederland zijn gepleegd. Van de vier onderzochte groepen zijn alleen Marokkanen verplicht een inburgeringsexamen met goed gevolg te voltooien, alvorens zij naar Nederland kunnen migreren. Bovendien moeten zij ook in Nederland een inburgeringscursus volgen. Echter de termijn waarop ze het examen moeten halen, strekt zich uit tot voorbij het moment waarop ze zijn geïnterviewd. We verwachten dus met name een invloed van investeringen in taal vóór migratie. Er zou verwacht kunnen worden dat migranten die (verplicht) moeten inburgeren de taal relatief kort na migratie al beter spreken dan degenen die dit niet hoeven. 
De invloed van taalinvesteringen is moeilijk te onderzoeken met een dwarsdoorsnede van recente migranten, omdat het binnen een groep juist de mensen met de minste taalvaardigheid zouden kunnen zijn die bijvoorbeeld een taalcursus volgen. We zullen dit exploratief onderzoeken.

\section{Het beheersen van een derde taal}

De hiervoor genoemde verwachtingen zijn grotendeels al eens eerder onderzocht, zij het nog niet voor recente migranten. Wat nog relatief onderbelicht is gebleven in eerder onderzoek, is wat de rol is van het beheersen van een derde taal voor tweedetaalverwerving (of eigenlijk wat de rol is van het beheersen van een tweede taal, voor de derdetaalverwerving). Een hypothese die vaak specifiek voor de Nederlandse situatie wordt geopperd, is dat migranten in Nederland nauwelijks de kans krijgen om Nederlands te leren, omdat autochtone Nederlanders in het Engels met ze gaan praten. De verwachting die hieruit voortvloeit, is dat wanneer migranten een taal spreken waarmee ze in Nederland goed uit de voeten kunnen, dus Engels of Duits, ze minder drijfveren hebben om de Nederlandse taal te leren. Er is onderzoek gedaan, met name in de taalwetenschappen, waaruit blijkt dat het beheersen van een 'derde taal' juist behulpzaam kan zijn bij het leren van een tweede taal (bijv. Cenoz 2003). De centrale verklarende factor hierbij is dat personen die niet alleen hun herkomsttaal beheersen, maar ook bijvoorbeeld het Engels of Duits, in het algemeen meer taalgevoel hebben en als gevolg daarvan ook eerder een nieuwe taal leren.

\section{Data}

We maken gebruik van de Nederlandse data van de dataverzameling 'Sociaal-Culturele Integratie Processen (SCIP)' onder recente migranten. Het CBS heeft een steekproef getrokken onder volwassen migranten die zich in hebben geschreven in de Gemeentelijke Basis Administratie tussen 1 september 2009 en half september 2010 (GBA) en afkomstig waren uit Polen, Bulgarije, Turkije, Marokko, de Nederlandse Antillen en Suriname, en die ook de nationaliteit van het betreffende land hadden. Alleen gemeenten werden geselecteerd waar in de betreffende periode minimaal 25 migranten uit een groep naartoe migreerden. Voor Poolse migranten, die zich nogal verspreid over het land vestigen, is vervolgens een selectie gemaakt van de 38 gemeenten waar zich de meeste Polen vestigen. Door de steekproef te trekken uit de GBA vallen migranten die zich niet in de GBA inschrijven vanzelfsprekend buiten het bereik. Naar verwachting zijn dat met name kort verblijvende migranten uit Polen en Bulgarije die slechts tijdelijk in Nederland verblijven om te werken. Als zij in loondienst zijn in Nederland staan ze wel in het werknemersregister ingeschreven, maar vaak niet in de bevolkingsregisters. Dit laatste hoeft pas als men van plan is langer dan vier maanden te blijven. Het SCIP-survey richt zich op integratieprocessen, waarbij de verwachting is dat migranten die zich inschrijven in de GBA naar alle waarschijnlijkheid een langer verblijfsperspectief voor ogen hebben. Voor de overige groepen (Marokkanen, Antillianen, Surinamers en Turken) is inschrijving in de GBA de enige formele 
weg om - in de periode van dit onderzoek - te migreren naar Nederland. In deze bijdrage richten we ons niet op de Surinaamse en Antilliaanse recente migranten, omdat zij vaak het Nederlands als moedertaal hebben.

Vanaf november 2010 zijn de migranten face-to-face benaderd, na een uitnodiging per brief te hebben ontvangen, en hebben ze mee kunnen doen met een face-to-faceinterview (via CAPI). De interviewer had een herkomst gelijk aan die van de beoogde respondent. Voor de Turken en Marokkanen is er daarnaast ook voor gezorgd dat mannelijke interviewers niet naar potentiële respondenten van het vrouwelijke geslacht gingen. Het interview werd afgenomen in de taal van het land van herkomst. Het veldwerk heeft geduurd van november 2010 tot juni 2011. In januari 2011 heeft het CBS nieuwe adressen aangeleverd van migranten die naar Nederland zijn gekomen in de periode september 2010-december 2010. Tijdens het veldwerk kwam naar voren dat de adressen van vooral Bulgaren en Polen vaak onjuist waren. Interviewers kregen vaak te horen dat de betreffende persoon er niet (meer) woonde. Ook is het percentage niet-thuis getroffen Polen en Bulgaren hoger dan onder de andere groepen.

Het netto responspercentage ligt het hoogst onder Turken (67\%), in overeenstemming met eerder onderzoek onder migrantengroepen in Nederland. Turken werden het beste bereikt en weigerden het minst vaak. Onder Marokkanen is het responspercentage juist laag (37\%). Alhoewel onder deze groep 66\% meedeed als ze werden bereikt, werd slecht 56\% bereikt. De Marokkaanse interviewers gaven herhaaldelijk aan dat de Marokkanen die zij aan de deur troffen sterk wantrouwend waren. Het aantal onjuiste adressen was - zoals vermeld - hoog onder de Polen en Bulgaren (respectievelijk 32\% en 37\%). Op adressen waar zes maal niemand thuis werd aangetroffen, bestaat eveneens de kans dat de migrant er niet langer woont. Het niet thuis treffen van de migrant kwam relatief vaak voor onder Marokkanen en Bulgaren. In totaal zijn 2590 interviews gerealiseerd onder de vier geselecteerde groepen (zie bijlage 1 voor meer informatie over het veldwerk).

De vrijheid van het reizen binnen de EU maakt de GBA een minder goed instrument om migratiestromen te meten. Hoewel Polen als migrant worden geregistreerd door het CBS als zij zich inschrijven in een gemeente, kwam in het interview naar voren dat de migratiedatum vaak al veel vroeger in de tijd lag. Voor Bulgaren gold dit in mindere mate en voor de niet-EU-migranten was de inschrijving in de GBA grotendeels gelijk aan de gegeven migratiedatum. In ons onderzoek zullen we dan ook controleren voor de tijd die in Nederland is verbleven. Er bestaat hier uiteraard een selectie-effect, waarbij Polen en Bulgaren die zich reeds uit hebben geschreven en zijn geremigreerd minder lang wilden verblijven. Hieruit zou dan moeten volgen dat onder Polen en Bulgaren verblijfsduur een sterker effect op taalbeheersing had dan onder de andere groepen. We zullen hiervoor controleren. Wel hebben we besloten om Polen en Bulgaren die aangaven langer dan vier jaar in Nederland te verblijven uit de analyses te laten (het gaat om circa honderd Polen en vijftig Bulgaren). Voor de Turken en Marokkanen houden we een verblijfsduur aan van maximaal twee jaar (twee jaar is gelijk aan de periode 
tussen de vier maanden voor de eerste inschrijving waarop de steekproef zich baseert, en de laatste maand waarin de gegevens zijn verzameld).

Het onderzoek maakt deel uit van het internationale door Norface gefinancierde SCIP (Causes and consequences of Social and Cultural Integration Processes among recent immigrants in Europe) project, waarbij identieke surveys zijn uitgevoerd in Duitsland, Engeland (alleen in Londen en via 'RDS' (respondent driven sampling)) en Ierland (alleen in Dublin en via RDS). In Duitsland is het onderzoek net als in Nederland gebaseerd op een aselecte steekproef uit het bevolkingsregister, maar alleen in de zes grootste steden en alleen onder Polen en Turken. We zien daarom af van een vergelijking tussen de landen.

Ten opzichte van eerder onderzoek heeft het SCIP-onderzoek duidelijk een aantal sterke kanten (Gijsberts en Lubbers 2013). Allereerst is niet eerder onderzoek gedaan naar migranten die nog maar zo kort in Nederland verblijven. Dit maakt het mogelijk hun 'startsituatie' - nog zo min mogelijk vertekend of veranderd door activiteiten en gebeurtenissen na hun migratie - goed in kaart te brengen. Een ander pluspunt betreft de onderzochte groepen. Het was niet eerder mogelijk een steekproef van Poolse en Bulgaarse - in GBA ingeschreven - migranten met elkaar (en met andere recent binnengekomen migranten) te vergelijken.

Het onderzoek heeft echter ook beperkingen. We kunnen bijvoorbeeld uitsluitend een beeld geven van de - recente - migranten die zich in de GBA hebben ingeschreven en dus niet van degenen die dat niet hebben gedaan. Wie van plan is om meer dan vier maanden in Nederland te verblijven, moet zich inschrijven in de Gemeentelijke Basisadministratie. We weten echter dat er beduidend meer Polen en Bulgaren in Nederland wonen dan zijn ingeschreven in de Gemeentelijke Basisadministratie. Degenen die korter dan vier maanden blijven hoeven zich niet in te schrijven en van degenen die wel langer blijven, schrijft ook niet iedereen zich in. We beschrijven dus maar een deel van de in Nederland verblijvende populatie. Het CBS heeft bijvoorbeeld onlangs becijferd dat er een groep van tachtigduizend werknemers uit de MOE-landen in Nederland is die (nog) niet zijn ingeschreven (Wobma en Van der Vliet 2011). Dit zijn cijfers die afkomstig zijn uit de werknemersbestanden (WNB): personen die bij UWV geregistreerd staan als werknemer. Dit aandeel is de afgelopen vijf jaar verviervoudigd. Volgens het CBS gaat het om zeventigduizend Poolse werknemers die niet als inwoner staan ingeschreven in het GBA; en slechts om iets meer dan duizend niet-ingeschreven Bulgaarse en Roemeense werknemers. Er zijn ook schattingen gemaakt van het totaal aantal MOE-landers in Nederland, dus van ingeschrevenen (GBA en UWV) en niet-ingeschrevenen te samen (zie Van der Heijden et al. 2011, 2013). Op basis van hun meest recente schatting (over 2010) komen Van der Heijden et al. uit op een totaal aantal van tussen de 322.000 en 366.000 MOE-landers. Ze becijferen dat er in 2010 tussen de 160.000 en 182.000 Polen in Nederland verblijven, waarvan er circa 130.000 geregistreerd staan in GBA of WNB. Naar schatting 39.000 Polen zijn niet geregistreerd (23\% van de totale populatie Polen in Nederland). In 2010 zijn er volgens Van der Heijden et al. (2013) tussen de 34.000 en 44.000 Bulgaren in Nederland. Daarvan staan er bijna 14.000 geregistreerd en circa 25.000 niet geregistreerd (64\% van de populatie). Er lijken dus - als we afgaan op deze schat- 
tingen - beduidend meer Polen (77\%) dan Bulgaren (36\%) in Nederland geregistreerd te staan (in de GBA en/of bij het UWV als werknemer).

\section{Meetinstrumenten}

\section{Afhankelijke variabele}

Taalverwerving. Vier items meten de taalverwerving van migranten. De zelfevaluatie van de taalbekwaamheid betreft het begrijpen, spreken, lezen en schrijven van het Nederlands. Respondenten konden antwoorden of ze het erg goed, goed, niet goed, of helemaal niet beheersen. De taalbeheersing is het best waar het het begrijpen van de taal betreft en het minst goed waar het het schrijven van het Nederlands betreft. De vier dimensies hangen sterk samen. De laagste correlatie is die tussen het begrijpen en het schrijven van de taal $(r=0,65)$; uitgesplitst naar de vier migrantengroepen is deze correlatie het laagst onder de Polen $(r=0,53)$. Zoals ook uit eerder onderzoek is gebleken, vormen de vier items een schaal met een hoge betrouwbaarheid. De Cronbachs alpha varieert van 0,89 onder de Poolse migranten tot 0,96 onder de Turkse migranten. Uit de literatuur over taalverwerving blijkt dat zelfrapportage tot vergelijkbare resultaten leidt als inschattingen van de interviewer. Omdat de interviews zijn gehouden in de taal van het land van herkomst en de interviewers eveneens een overeenkomstige etnische achtergrond hebben, zou het echter zo kunnen zijn dat ook de inschatting door de interviewer problemen met zich meebrengt. De 0,3 procent van de respondenten zonder score op taalvaardigheid zijn uit de analyses gelaten.

\section{Onafhankelijke variabelen}

Intentie om te blijven. Er is gevraagd of men verwacht in Nederland te blijven wonen. Andere antwoordcategorieën waren: van plan te pendelen tussen Nederland en herkomstland, van plan terug te keren naar het herkomstland en van plan in een derde land te gaan wonen. Deze drie categorieën zijn op 0 gezet.

Contacten in Nederland voor migratie. Gevraagd is of men al mensen in Nederland kende voordat men migreerde ( $\mathrm{ja} / \mathrm{nee}$ ). Er is geen vraag gesteld over welke relatie men had met deze mensen die men al kende.

Bezoek aan Nederland voor migratie. Migranten is gevraagd of ze al dan niet voor een periode langer dan vier weken in Nederland zijn geweest voor de migratiedatum die ze zelf hebben aangegeven (en die dus afwijkt van de migratiedatum die geregistreerd staat in de GBA).

Verblijfsduur. Verblijfsduur is gespecificeerd in maanden en gebaseerd op de eigen opgave van de respondent.

Hoofdactiviteit. We onderscheiden 'werkend', 'werkloos', 'studerend', en 'anders' (waaronder huisvrouw/man en met zwangerschapsverlof). De ontbrekende antwoorden zijn ingedeeld bij 'anders'.

Contacten binnen de eigen groep en contacten met Nederlanders. Hoe vaak men tijd doorbrengt met mensen van de eigen etnische groep vormt de meting van sociale contacten in de eigen groep. Daarnaast is gevraagd hoe vaak men tijd doorbrengt met Nederlanders. Bulgaren die zich beschouwen als Turkse Bulgaren is tevens de 
vraag gesteld in hoeverre ze met Turken omgaan. Voor deze groep worden zowel Turken als Bulgaren als de eigen groep gedefinieerd. Dit omdat het niet duidelijk is of ze met Turken, 'Turkse Turken' bedoelen of Turkse Bulgaren.

(Gepercipieerde) aandeel herkomstgenoten in de buurt. Respondenten is gevraagd op een schaal van 1 tot 4 aan te geven hoe hoog het aandeel landgenoten in de eigen woonbuurt is.

Opleidingsniveau. Per migrantengroep is de opleidingscategorisering uit het land van herkomst gehanteerd. Het hoogst behaalde opleidingsniveau is gecodeerd naar laag, lager middelbaar, hoger middelbaar en hoger onderwijs. Indien een respondent in Nederland een hoger opleidingsniveau volgt is dit hogere opleidingsniveau toegekend. De ontbrekende waarden op opleiding worden apart als categorie onderscheiden.

Investering in de Nederlandse taal voor én na migratie. Gevraagd is of respondenten zowel voor als na migratie het Nederlands hebben geleerd, en op welke wijze. We nemen hier op of mensen wel of geen investering hebben gedaan in het Nederlands leren (ja/nee).

Het spreken van een derde taal. Aan alle respondenten is gevraagd of men Engels en of men Frans spreekt. Daarnaast is er aan alle groepen, behalve de Marokkanen, gevraagd of men Duits spreekt. De range van de variabelen is hetzelfde als bij de vragen over de Nederlandse taal ( 1 = helemaal niet; 4 = erg goed).

We controleren verder voor Partnerstatus en Kinderen in het huishouden ouder dan drie, zoals die door Van Tubergen en Kalmijn (2009) zijn geopperd als relevante kenmerken die mogelijkheden vergroten om de Nederlandse taal te gebruiken en te leren. Migranten is gevraagd of ze een partner hebben, waar hij of zij woonachtig is en wat het geboorteland van de partner is. Hiermee hebben we niet de mogelijkheid om tweedegeneratiepartners te onderscheiden. We onderscheiden migranten zonder partner van hen met een partner. De migranten met een partner zijn verder uitgesplitst naar: (1) partner geboren in land van herkomst samenwonend met de migrant; (2) partner geboren in Nederland samenwonend met de migrant; (3) partner geboren in een ander land, samenwonend met de migrant; (4) partner in Nederland maar niet samenwonend; (5) partner in het land van herkomst. Betreffende de meting van kinderen ouder dan drie in het huishouden, is er gevraagd naar de personen in het huishouden van de respondent, de relatie met deze personen en de leeftijd van deze personen. We onderscheiden hiermee respondenten met kinderen die in Nederland (hoogstwaarschijnlijk) op school zitten van respondenten die geen kinderen in deze leeftijd bij zich hebben wonen. Ten slotte controleren we voor geslacht en leeftijd. Geslacht is een $0 / 1$-variabele ( $1=\mathrm{man})$. Leeftijd is een continue variabele tussen de 18 en 65 jaar. Tabel 1 bevat de beschrijvende statistieken met betrekking tot de door ons gebruikte variabelen. 
Tabel 1 Beschrijvende statistiek (gemiddelden en percentages)

\begin{tabular}{|c|c|c|c|c|c|}
\hline & $\begin{array}{l}\text { Alle groepen } \\
\text { (range) }\end{array}$ & $\begin{array}{l}\text { Polen } \\
(n=724)\end{array}$ & $\begin{array}{l}\text { Bulgaren } \\
(\mathrm{n}=392)\end{array}$ & $\begin{array}{l}\text { Turken } \\
(n=752)\end{array}$ & $\begin{array}{l}\text { Marokka- } \\
\text { nen } \\
(n=343)\end{array}$ \\
\hline $\begin{array}{l}\text { Taalbeheersing in het } \\
\text { Nederlands }\end{array}$ & $I-4$ & $\mathrm{I}, 86$ & 1,76 & $\mathrm{I}, 74$ & 2,43 \\
\hline Intentie om te blijven & $0-1$ & $47,7 \%$ & $25,3 \%$ & $57,5 \%$ & $83,4 \%$ \\
\hline Maanden in NL & $0-48$ & 22,6 & $\mathrm{II}, \mathrm{I}$ & 10,7 & 10,4 \\
\hline Contacten NL voor migratie & $0-1$ & $55,8 \%$ & $54,9 \%$ & $57,3 \%$ & $60,4 \%$ \\
\hline Bezoek NL voor migratie & $0-1$ & $23,3 \%$ & $9,4 \%$ & $9,4 \%$ & $25,1 \%$ \\
\hline \multicolumn{6}{|l|}{ Bezigheid in NL } \\
\hline - werkend & $0-1$ & $78,5 \%$ & $35,5 \%$ & $40,3 \%$ & $29,2 \%$ \\
\hline - werkloos & $0-1$ & $7,3 \%$ & $32,7 \%$ & $30,6 \%$ & $32,7 \%$ \\
\hline - studerend & $0-1$ & $4,0 \%$ & $24,2 \%$ & $14,8 \%$ & $16,9 \%$ \\
\hline - anders & $0-1$ & $10,2 \%$ & $7,7 \%$ & $14,4 \%$ & $21,3 \%$ \\
\hline $\begin{array}{l}\text { Contactfrequentie met } \\
\text { Nederlanders }\end{array}$ & $0-3$ & 2,38 & 2,13 & $|, 3|$ & $\mathrm{I}, 70$ \\
\hline $\begin{array}{l}\text { Contactfrequentie binnen } \\
\text { de groep }\end{array}$ & $0-3$ & 2,59 & 2,64 & 2,41 & 2,25 \\
\hline $\begin{array}{l}\text { (gepercipieerde) aandeel } \\
\text { herkomstgenoten in de } \\
\text { buurt }\end{array}$ & I - 3 & 1,98 & $\mathrm{I}, 74$ & 2,40 & 2,56 \\
\hline \multicolumn{6}{|l|}{ Opleidingsniveau } \\
\hline- hoog & $0-1$ & $20,4 \%$ & $14,5 \%$ & $22,7 \%$ & $7,9 \%$ \\
\hline - hoger middelbaar & $0-1$ & $47,9 \%$ & $32,1 \%$ & $31,0 \%$ & $26,8 \%$ \\
\hline - lager middelbaar & $0-1$ & $26,1 \%$ & $25,0 \%$ & $13,6 \%$ & $10,5 \%$ \\
\hline - lager & $0-1$ & $2,9 \%$ & $24,5 \%$ & $31,1 \%$ & $44,0 \%$ \\
\hline - ontbrekend & $0-1$ & $2,6 \%$ & $3,8 \%$ & $1,6 \%$ & $10,8 \%$ \\
\hline $\begin{array}{l}\text { Taalinvestering voor } \\
\text { migratie }\end{array}$ & $0-1$ & $8,0 \%$ & $3,6 \%$ & $12,2 \%$ & $62,3 \%$ \\
\hline Taalinvestering na migratie & $0-1$ & $55,5 \%$ & $43,9 \%$ & $23,7 \%$ & $75,2 \%$ \\
\hline Taalbeheersing in het Engels & I - 4 & 2,52 & 2,16 & $\mathrm{I}, 87$ & 2,03 \\
\hline Taalbeheersing in het Duits & I - 4 & $\mathrm{I}, 64$ & 1,35 & 1,19 & n.a. \\
\hline Taalbeheersing in het Frans & I - 4 & 1,13 & 1,10 & 1,05 & 2,62 \\
\hline \multicolumn{6}{|l|}{ Partnerstatus } \\
\hline - geen partner & $0-1$ & $29,6 \%$ & $45,2 \%$ & $30,5 \%$ & $17,5 \%$ \\
\hline $\begin{array}{l}\text { - zelfde geboorteland, } \\
\text { binnen huishouden }\end{array}$ & $0-1$ & $56,5 \%$ & $42,4 \%$ & $30,7 \%$ & $44,3 \%$ \\
\hline $\begin{array}{l}\text { - NL geboorteland, binnen } \\
\text { huishouden }\end{array}$ & $0-1$ & $3,2 \%$ & $0,3 \%$ & $27,9 \%$ & $18,4 \%$ \\
\hline $\begin{array}{l}\text { - ander geboorteland, } \\
\text { binnen huishouden }\end{array}$ & $0-1$ & $4,3 \%$ & $2,0 \%$ & $3,9 \%$ & $5,0 \%$ \\
\hline
\end{tabular}


Tabel 1 (Vervolg)

\begin{tabular}{llllll}
\hline & $\begin{array}{l}\text { Alle groepen } \\
(\text { range })\end{array}$ & $\begin{array}{l}\text { Polen } \\
(\mathbf{n}=\mathbf{7 2 4})\end{array}$ & $\begin{array}{l}\text { Bulgaren } \\
(\mathbf{n}=\mathbf{3 9 2})\end{array}$ & $\begin{array}{l}\text { Turken } \\
(\mathbf{n}=\mathbf{7 5 2})\end{array}$ & $\begin{array}{l}\text { Marokka- } \\
\mathbf{n e n} \\
(\mathbf{n}=\mathbf{3 4 3})\end{array}$ \\
\hline $\begin{array}{l}\text { - wonend in land van } \\
\text { herkomst }\end{array}$ & $0-1$ & $6,4 \%$ & $7,6 \%$ & $5,5 \%$ & $2,3 \%$ \\
- wonend in Nederland & $0-1$ & $0,1 \%$ & $2,6 \%$ & $1,6 \%$ & $12,5 \%$ \\
$\begin{array}{l}\text { Kind in huishouden ouder } \\
\text { dan drie }\end{array}$ & $0-1$ & $16,9 \%$ & $16,6 \%$ & $13,4 \%$ & $10,8 \%$ \\
$\begin{array}{l}\text { Man } \\
\text { Leeftijd }\end{array}$ & $0-1$ & $47,2 \%$ & $43,1 \%$ & $57,3 \%$ & $48,1 \%$ \\
\hline
\end{tabular}

De beschrijvende tabel bevat veel informatie over de vier recente migrantengroepen. Omdat er nog weinig bekend is over migranten die recentelijk naar Nederland zijn gemigreerd, zeker waar het de Bulgaren betreft, bespreken we kort de verschillen tussen de groepen.

Betreffende de afhankelijke variabele zien we dat de taalbeheersing onder Polen, Bulgaren en Turken laag is. Op de schaal van 1 tot 4 scoren zij lager dan een 2 . Marokkanen doen het wat beter, met een gemiddelde score van 2,43. Kijken we wat nader naar de frequentieverdelingen, dan zien we dat de meerderheid van de recent gemigreerde Polen en Bulgaren moeite heeft met de Nederlandse taal (figuur 2). Als we bijvoorbeeld kijken naar het verstaan van het Nederlands, dan blijkt dat $66 \%$ van de Polen en $68 \%$ van de Bulgaren de Nederlandse taal niet of niet goed verstaat. Deze bevinding sluit aan bij eerder onderzoek, met name uitgevoerd onder Polen in Nederland (bijv. Dagevos 2011; Weltevrede et al. 2009) en is niet verwonderlijk gezien de relatief korte periode dat ze in Nederland wonen. Een op de drie zegt het Nederlands wel goed te verstaan. Gezien het korte verblijf van deze migranten is dit overigens een niet onaanzienlijk aandeel. Bij de Turken die net in Nederland zijn, is het aandeel dat Nederlands verstaat veel lager (22\%). $\mathrm{Bij}$ de recent gemigreerde Marokkanen is het aandeel dat Nederlands zegt te verstaan met 53\% veruit het hoogst. Dat de Turks-Nederlandse groep het Nederlands gemiddeld genomen minder goed beheerst dan bijvoorbeeld de Marokkaans-Nederlandse groep komt uit veel eerder onderzoek naar voren (bijv. Gijsberts en Dagevos 2009), maar zo'n groot verschil als we hier bij recente migranten zien, wordt doorgaans niet aangetroffen. Het zou te maken kunnen hebben met het feit dat Marokkanen wel onder de Wet Inburgering Buitenland vallen (en voor hun komst een inburgeringsexamen in het land van herkomst met goed gevolg moeten hebben afgesloten) en Turken niet meer. Maar we kunnen ook niet uitsluiten dat er een relatie is met moeizamere dataverzameling onder de Marokkaanse groep recent gemigreerden, zoals hierboven beschreven.

De Marokkanen hebben het sterkst de intentie om in Nederland te blijven $(83,4 \%)$, de Bulgaren het minst $(25,3 \%)$. Tussen een kwart (onder de Polen en Marokkanen) en een tiende (onder Bulgaren en Turken) bezocht Nederland al eens langer dan vier weken voordat ze besloten naar Nederland te migreren en 


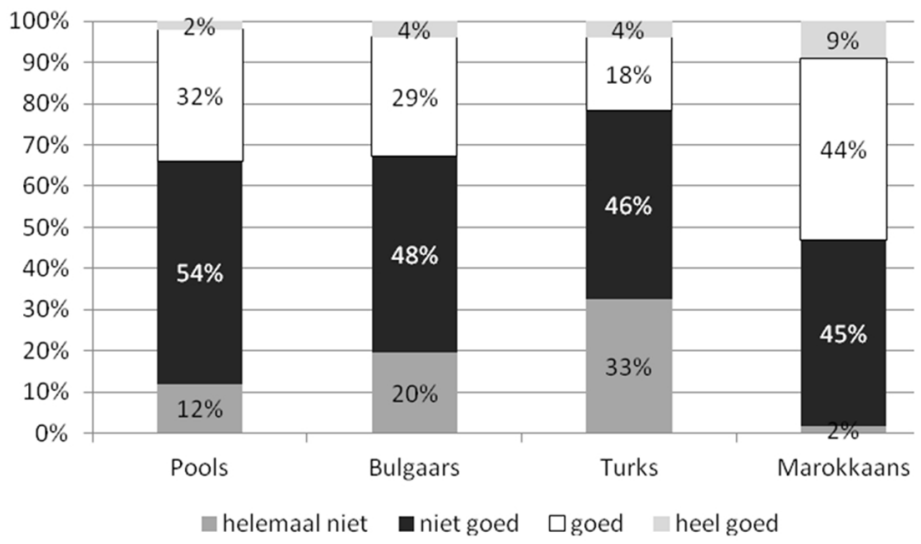

Figuur 2 Verstaan van het Nederlands naar etnische herkomst, 2011 (in procenten)

het percentage van de migranten dat al contacten had in Nederland ligt voor alle groepen tussen de 55 en 60 procent.

Het grootste deel van de Polen is werkzaam. Onder de andere groepen, ook onder de Bulgaren, zegt meer dan 30\% werkloos te zijn. Van de Bulgaren volgt bijna een kwart een opleiding in Nederland. Dit zijn bijna allemaal studiemigranten die een studie volgen in het Nederlandse hoger onderwijs. Contacten met Nederlanders komen beduidend vaker voor onder Polen en Bulgaren dan onder Marokkanen en vooral Turken. Dit laatste is ook al in veel eerder onderzoek naar voren gekomen. De contactfrequenties binnen de eigen groep ontlopen elkaar niet veel, hoewel ze wat lager zijn onder de Marokkanen, en zijn voor alle groepen als frequent aan te duiden. De inschatting van het aandeel bewoners uit de eigen groep weerspiegelt de grootte van de groepen in Nederland. Bulgaren geven nauwelijks aan dat zij in buurten wonen met veel andere Bulgaren. Turken en Marokkanen benoemen dit frequenter.

Het opleidingsniveau verschilt behoorlijk tussen de groepen. Terwijl de Polen vaak hoog opgeleid zijn, zijn de Bulgaren en vooral de Marokkanen vaak laag opgeleid.

$\mathrm{Na}$ migratie hebben recente migranten veel vaker getracht zich het Nederlands eigen te maken dan voor migratie. Alleen Marokkanen zeggen vaak voor migratie al iets gedaan te hebben. Dit lijkt te duiden op de voorbereiding voor het inburgeringsexamen in het buitenland. Na migratie hebben Marokkanen en Polen het vaakst geïnvesteerd in het leren van de taal. Het aandeel onder de Turken is veruit het laagst.

Poolse recente migranten rapporteren de beste Engelse taalbeheersing; de Turken de slechtste. En hoewel onder alle groepen de taalbeheersing van het Duits laag is, is deze het beste onder de Polen (nadere inspectie leert dat van hen $16 \%$ aangeeft het Duits te beheersen). Frans wordt alleen redelijk onder de Marokkanen beheerst; ruim de helft van de Marokkanen zegt Frans te spreken. 
Bulgaarse migranten zijn het vaakst alleenstaand. Dit heeft ook te maken met het feit dat er zich in de Bulgaarse groep recent gemigreerden relatief veel studiemigranten bevinden (ongeveer een kwart van de groep recent gemigreerden). Indien de migranten een partner hebben, is deze meestal geboren in het hetzelfde land als de migrant. Onder Turken en Marokkanen is tevens een groot deel van de partners geboren in Nederland. Het percentage migranten met partners geboren in een ander land dan het land van herkomst of Nederland ligt voor de meeste groepen rond de $4 \%$. Onder alle groepen heeft tussen de tien en twintig procent een thuiswonend kind ouder dan drie. In de data zijn vrouwen iets sterker vertegenwoordigd, vooral onder de Turken (in de populatie van recente Turkse migranten is de verhouding nog schever en is zestig procent man). In de populatie is de sekseverdeling bij de andere groepen rond de vijftig-vijftig; in de data ligt het percentage mannen voor de Marokkanen, Polen en Bulgaren wat onder de vijftig procent. De gemiddelde leeftijd van de migranten is voor alle groepen rond de dertig.

\section{Bevindingen}

In tabel 2 presenteren we de resultaten van OLS-regressieanalyses voor de vier migrantengroepen apart. We doen geen gepoolde analyses omdat we willen zien of de verklaringen verschillen tussen de migrantengroepen. Op voorhand merken we op dat er vanzelfsprekend mediatieprocessen plaatsvinden in de modellen. Daarom hebben we de modellen stapsgewijs opgebouwd (opvraagbaar bij de auteurs).

Met betrekking tot de verblijfsintentie vinden we alleen voor de Turken een significant positief effect. Turkse migranten die van plan zijn in Nederland te blijven, spreken kort na hun migratie al beter Nederlands. Voor de Bulgaren en Marokkanen is het effect significant op het niveau $\mathrm{p}<.10$. Er zijn dus aanwijzingen dat een langduriger verblijfsperspectief positief bijdraagt aan taalbeheersing, maar het effect is niet sterk. We zien dat er een duidelijk effect is van verblijfsduur. Zelfs bij deze recente migranten zien we al dat degenen die wat langer in Nederland zijn, de Nederlandse taal beter beheersen. Alleen voor de recente migranten uit Marokko is er geen verband. Ook eerdere bezoeken aan Nederland (vóór migratie) werken positief uit op de verwerving van het Nederlands, echter niet voor de Polen. Voor deze groep, anders dan voor de andere groepen, draagt juist het al kennen van mensen in Nederland voor migratie bij aan het verwerven van het Nederlands.

Voor de verwachting dat werkenden beter Nederlands spreken dan degenen zonder werk vinden we enigszins ondersteuning. Bulgaarse en Marokkaanse werklozen beheersen het Nederlands minder goed dan zij die werken. Opvallend is dat de groep studerende Bulgaren, Turken en Marokkanen het Nederlands ook minder goed beheerst dan de werkenden. Vooral onder Bulgaarse studenten zien we dat zij vaak een Engelstalige master volgen, wat een verklaring zou kunnen zijn voor hun mindere noodzaak tot het leren van het Nederlands. Daarnaast zien we een opleidingseffect, althans voor Bulgaren en Marokkanen: de hoger opgeleide 
recente migranten spreken beter Nederlands dan hun lager opgeleide herkomstgenoten. Voor Polen en Turken is het opleidingseffect echter afwezig.

Een robuuste associatie vinden we tussen het hebben van contacten met Nederlanders en Nederlandse taalbeheersing. Contacten met autochtone Nederlanders gaan samen met een betere taalbeheersing. En deze relatie geldt voor alle vier recente migrantengroepen. Voor Turkse en Marokkaanse recente migranten geldt daarnaast ook dat meer contacten binnen de eigen groep samengaan met een slechtere beheersing van het Nederlands. Dus uitsluitend voor deze twee groepen belemmert het omgaan met veel herkomstgenoten het verwerven van de Nederlandse taal. Dat we dit effect alleen voor deze twee groepen vinden, ligt voor de hand omdat er in Nederland al een grote Marokkaanse en Turkse gemeenschap is, en zij ook vaak geconcentreerd wonen. Voor de Polen en Bulgaren is dit veel minder het geval. Zoals al eerder vermeld, is hier sprake van een causaliteitsprobleem. Meer contacten met Nederlanders kunnen leiden tot een betere taalbeheersing, maar een betere taalbeheersing maakt die contacten ook weer mogelijk. Er is hier waarschijnlijk eerder sprake van wederzijdse beïnvloeding dan dat de causaliteit uitsluitend één richting uit loopt. Het (gepercipieerde) aandeel herkomstgenoten in de eigen woonbuurt heeft echter voor geen van de groepen het verwachte effect. Voor Turkse recente migranten is het effect weliswaar significant maar in de omgekeerde richting.

Degenen die voor migratie al inspanningen hebben verricht om Nederlands te leren, spreken de taal ook daadwerkelijk beter. We vinden dit effect echter niet voor de Marokkanen. En hetzelfde geldt voor inspanningen die sinds migratie zijn verricht.

Richten we nu onze aandacht op de veel gehoorde veronderstelling dat migranten die een derde taal spreken, minder hun best zullen doen Nederlands te leren en derhalve een lagere beheersing van het Nederlands zullen hebben. De taal die het meest in aanmerking komt om dit voor de Nederlandse situatie te onderzoeken is het Engels. We vinden echter - gecontroleerd voor alle andere variabelen - geen enkel negatief effect van het spreken van het Engels op de taalbeheersing in het Nederlands. Voor de meeste groepen is er geen effect van het spreken van het Engels, alleen voor de Turken vinden we een significant effect, maar dan een positief effect. De alternatieve hypothese dat het spreken van een derde taal juist behulpzaam is bij het leren van de tweede taal, vindt hier dus eerder ondersteuning. We vinden het namelijk ook voor de Polen, Bulgaren en Turken met betrekking tot het Duits en voor de Marokkanen met betrekking tot het Frans (tabel 2). Weliswaar controleren we voor het opleidingsniveau, maar klaarblijkelijk is het zo dat mensen die een tweede taal spreken, toch in het algemeen meer taalgevoel hebben, of andere gunstige kenmerken, die het leren van een nieuwe taal bespoedigen.

Ten slotte vinden we dat onder Polen personen met een partner in het huishouden die geboren is in Nederland, beter Nederlands spreken. Voor Polen, Bulgaren en Turken doet dit effect zich ook voor als de partner niet in het huishouden woont. We weten overigens niet of dit een partner uit de eigen etnische groep of uit een andere etnische groep is. Poolse en Turkse migranten zonder partner spreken overigens ook beter Nederlands dan degenen met een partner. Dit is al in eer- 
der onderzoek aangetoond. Voor Bulgaren en Marokkanen vinden we echter geen effect. We vinden geen relatie tussen het hebben van schoolgaande kinderen in het Nederlandse onderwijs en de beheersing van de Nederlandse taal.

Tabel 2 Lineaire regressieanalyse van taalvaardigheid in het Nederlands voor recente migranten uit Polen, Bulgarije, Turkije en Marokko




Tabel 2 (Vervolg)

\begin{tabular}{lllllllll}
\hline & \multicolumn{2}{l}{ Polen } & \multicolumn{2}{c}{ Bulgaren } & \multicolumn{2}{c}{ Turken } & \multicolumn{2}{c}{ Marokkanen } \\
& B & Se & B & Se & B & Se & B & Se \\
\hline Leeftijd &,- 002 &, 003 &, 004 &, 003 &, 004 &, 003 & $-, 012,004 * *$ \\
(constante) & $1,148,202 * *$ &, 893 &, 213 & $* *$ &, 061 &, 176 & $2,270,251 * *$ \\
R2 & 0,39 & & 0,48 & & 0,47 & & 0,28 \\
N & 723 & & 391 & & 751 & & 342 \\
\hline
\end{tabular}

$\sim \mathrm{p}<.10 ; *^{*}<.05 ; * * p<.01$

In tabel 3 vatten we de bevindingen samen door per onderzochte groep te bezien welke verwachtingen wel en welke niet worden ondersteund.

Tabel $3 \quad$ Uitkomsten van de hypothesen

\begin{tabular}{lllll}
\hline & Polen & Bulgaren & Turken & Marokkanen \\
\hline Intentie om in NL te blijven & 0 & + & + & + \\
Verblijfsduur & + & + & + & 0 \\
Eerder verblijf in NL & 0 & + & + & + \\
Contacten in NL voor migratie & + & 0 & 0 & 0 \\
Werk in Nederland & 0 & + & 0 & + \\
Contacten met Nederlanders & + & + & + & + \\
Contacten in de eigen groep & 0 & 0 & - & - \\
Herkomstgenoten in buurt & 0 & 0 & + & 0 \\
Opleidingsniveau & 0 & + & 0 & + \\
Taalinvestering voor migratie & + & + & + & 0 \\
Taalinvestering na migratie & + & + & + & 0 \\
Spreekt derde taal (Engels/Duits/Frans) & $0 /+/+$ & $0 /+/ 0$ & $+/+/ 0$ & $0 / \mathrm{na} /+$ \\
\hline
\end{tabular}

$0=$ geen significant effect; + = positief significant effect (toename taalvaardigheid in het Nederlands; - = negatief significant effect (afname taalvaardigheid in het Nederlands)

\section{Conclusie}

Uit dit onderzoek kunnen een aantal conclusies worden getrokken. Allereerst is duidelijk dat de (zelfgerapporteerde) taalvaardigheid in het Nederlands van migranten vrij kort na hun migratie te wensen overlaat. Toch zegt een op de drie recente migranten het Nederlands al te kunnen verstaan. Gezien hun korte verblijfsduur is dit een niet onaanzienlijk aandeel. Er wordt vaak gezegd dat de eerste fase na migratie cruciaal is voor het welslagen van integratie (bijv. Phinney 2001). In dat opzicht heeft een deel van deze recente migranten al belangrijke stappen gezet in de beheersing van de taal van het bestemmingsland. We vinden niet voor niets een belangrijk effect van de verblijfsduur: hoe meer maanden men in Nederland is, hoe beter het Nederlands al wordt beheerst. We vinden ook enige ondersteuning voor het belang van verblijfsintentie. Als men van plan is te blijven, 
investeert men meer in het leren van de taal, zoals uit ons onderzoek blijkt. Veel van deze recente migranten hebben al pogingen ondernomen om de taal te leren sinds ze in Nederland zijn aangekomen. Deze inspanningen blijken zo kort na migratie al lonend. Degenen die geïnvesteerd hebben in het leren van de taal, of dat nu via taalcursussen, zelfstudie of via vrienden en bekenden is, spreken de taal al beter dan degenen die dit niet hebben gedaan. Overigens doen Polen, Bulgaren en Turken dit nauwelijks voor migratie.

Een andere belangrijke conclusie is dat ook gelegenheidsargumenten een rol spelen bij het verwerven van de taal van het bestemmingsland. Migranten die in Nederland werken, komen meer in aanraking met de Nederlandse taal en dit blijkt goed voor de taalverwerving. Ook een Nederlandse partner helpt hierbij. Bovendien kun je voor het verwerven van de Nederlandse taal beter geen partner hebben, dan een partner uit de eigen herkomstgroep. We vinden echter geen effect van het hebben van kinderen op een leeftijd waarop ze in Nederland naar school gaan.

Daarnaast spelen hulpbronnentheorieën een rol. Migranten die hoger zijn opgeleid beschikken over meer kapitaal en dit maakt het leren van een nieuw taal eenvoudiger. Ook zien we dat er een belangrijke rol is weggelegd voor de sociale context waarin men in Nederland verkeert. Hoe de causaliteit ook precies verloopt, het is een feit dat recente migranten die veel met autochtone Nederlanders omgaan, beter Nederlands spreken. Dit geldt voor alle in deze studie onderzochte migrantengroepen. Voor recente migranten uit Turkije en Marokko geldt daarnaast bovendien dat veel contacten binnen de eigen groep een belemmerende rol spelen in het verwerven van de Nederlandse taal. Dat we deze negatieve effecten wel voor deze gevestigde groepen vinden en niet voor de nieuwkomers uit Bulgarije en Polen, heeft waarschijnlijk veel te maken met verschillen in groepsgrootte en mate van woonconcentraties tussen de Turkse en Marokkaanse groepen enerzijds en de Poolse en Bulgaarse groepen anderzijds.

Een laatste conclusie betreft de invloed van het spreken van een derde taal. De alom gehoorde uitspraak dat migranten in Nederland geen Nederlands leren, omdat ze zich toch wel in het Engels (of Duits) kunnen redden, vindt geen empirische ondersteuning. We vinden geen enkele negatieve samenhang tussen het spreken van een derde taal en de beheersing van het Nederlands. Sterker nog, we vinden voor alle groepen juist eerder positieve invloeden. Polen, Bulgaren en Turken die ook Duits spreken, Turken die het Engels beter spreken en Marokkanen die het Frans beter spreken, beheersen het Nederlands beter dan zij die dat niet of minder goed doen. Het beheersen van een derde taal is dus eerder behulpzaam bij het leren van de Nederlandse taal dan dat het een belemmerende rol speelt. Dit ondersteunt theorieën uit de taalwetenschappen over de invloed van derde talen (Cenoz 2003).

Een van de beperkingen van het onderzoek betreft de generaliseerbaarheid van onze uitkomsten. Het onderzoek is alleen gehouden onder recente migranten die zich in een bepaalde periode inschreven in het Nederlandse bevolkingsregister. We kunnen dus alleen uitspraken doen over recente migranten uit de vier onderzochte groepen en niet over de gehele populatie in Nederland. Bovendien missen we diegenen die in Nederland zijn gaan wonen zonder dat ze staan ingeschreven. 
Het zou goed kunnen dat de taalbeheersing onder deze groep nog wat lager is, omdat een deel van deze groep naar alle waarschijnlijkheid een meer tijdelijk verblijfsperspectief voor ogen heeft (zie Snel et al. 2013). Het zou mooi zijn in toekomstig onderzoek beide groepen op te nemen (dus zowel de wel- als nietingeschrevenen) om een completer beeld te kunnen geven. Bovendien kunnen de vragen die we hier gesteld hebben over de taalbeheersing van recente migranten naar Nederland nog beter worden beantwoord in een studie met een longitudinaal design. De migranten die in de studie waarop deze bijdrage is gebaseerd hebben meegedaan, worden binnen twee jaar nadat zij met het onderzoek hebben meegedaan opnieuw benaderd. Dit biedt een uitgelezen kans om te onderzoeken hoe de taalverwerving onder recente migranten die in Nederland blijven verloopt. Voor de inpassing in de Nederlandse samenleving is het spreken van de taal een belangrijke voorwaarde. We zagen in deze studie dat recente migranten uit Marokko het Nederlands relatief gezien het beste lijken te beheersen. We kunnen niet uitsluiten dat deze bevinding te wijten is aan mogelijke selectiviteit in de respons (het onderzoek verliep moeilijk onder de recente migranten uit Marokko), maar toch is dit ook de enige groep van de hier onderzochte groepen die verplicht dient in te burgeren. Recent gemigreerde Turken spreken het Nederlands het minst goed. Zoals we uit eerder onderzoek weten, is hier een duidelijke relatie met de interne gerichtheid van de Turkse groep. De bevindingen maken echter duidelijk dat het jammer is dat juist Turkse migranten zijn uitgesloten van het inburgeringsstelsel in Nederland. Om hun weg in Nederland te vinden, kunnen zij ondersteuning bij het leren van de taal goed gebruiken.

Ook onder Polen en Bulgaren is nog veel te winnen met betrekking tot het leren van de Nederlandse taal. Vooral de Bulgaarse groep, de groep met de minste hulpbronnen gezien het lage opleidingsniveau van een deel van hen, heeft een grote kloof te overbruggen. Zij staan ook gezien hun lage arbeidsparticipatie op grotere afstand van de Nederlandse samenleving dan de Polen (zie Lubbers en Gijsberts 2013). Eerder onderzoek laat zien dat een deel van de Bulgaren en Polen van plan is zich hier blijvend te vestigen. Veel Polen en Bulgaren zijn hier bijvoorbeeld al met partner en/of kinderen. We hebben hier laten zien dat degenen met de intentie hier te blijven meer geneigd zijn te investeren in de taal van het bestemmingsland. Van belang is het dan om in een zo vroeg mogelijk stadium de taal te leren - de eerste fase na migratie is immers cruciaal - en zoals we in het verleden hebben gezien bij de eerste generatie Turkse en Marokkaanse migranten komt van uitstel vaak afstel. Daarom verdient het aanbeveling als Nederlandse overheid taalcursussen voor EU-burgers te faciliteren. Het al dan niet volgen van een taalcursus hangt nu vaak af van een welwillende werkgever. Het aanbieden van taalcursussen zal ten goede komen aan de participatie van deze groepen in de samenleving en op de arbeidsmarkt.

\section{Literatuur}

Carliner, G. (2000) The Language Ability of U.S. Immigrants: Assimilation and Cohort Effects. International Migration Review, 34: 158-182. 
Cenoz, J. (2003) The additive effect of bilingualism on third language acquisition: A review. The International Journal of Bilingualism, 7: 71-87.

Chiswick, B.R. en P.W. Miller (1996) Ethnic networks and language proficiency among immigrants. Journal of Population Economics, 9: 19-35.

Chiswick, B.R. en P.W. Miller (2001) A Model of Destination Language Acquisition: Application to Male Immigrants in Canada. Demography, 38: 391-409.

Dagevos, J. (red.) (2011) Poolse migranten: de positie van Polen die vanaf 2004 in Nederland zijn komen wonen. Den Haag: Sociaal en Cultureel Planbureau.

Driessen, G. (2004) De taalsituatie van Caribische en Mediterrane migranten: Ontwikkelingen in taalvaardigheid en taalkeuzes in Antilliaanse, Surinaamse, Turkse en Marokkaanse gezinnen gedurende de periode 1995-2003. Migrantenstudies, 20: 74-93.

Engbersen, G., M. Ilies, A.S. Leerkes, E. Snel en R. van der Meij (2011) Arbeidsmigratie in vieren: Bulgaren en Roemenen vergeleken met Polen. Rotterdam: Erasmus Universiteit Rotterdam (Afdeling Sociologie).

Gijsberts, M. en J. Dagevos (2007) The socio-cultural integration of ethnic minorities in the Netherlands: Identifying neighbourhood effects on multiple integration outcomes. Housing Studies, 22: 805-831.

Gijsberts, M. en J. Dagevos (red.) (2009) Jaarrapport Integratie 2009. Den Haag: Sociaal en Cultureel Planbureau.

Gijsberts, M. en M. Lubbers (2013) Nieuw in Nederland: Het leven van recent gemigreerde Bulgaren en Polen. Den Haag: Sociaal en Cultureel Planbureau.

Heijden, P.G.M. van der, M. Cruyff en G. van Gils (2011) Aantallen geregistreerde en nietgeregistreerde burgers uit MOE-landen die in Nederland verblijven. Utrecht: Universiteit Utrecht.

Heijden, P.G.M. van der, M. Cruyff en G. van Gils (2013) Aantallen geregistreerde en nietgeregistreerde burgers uit MOE-landen die in Nederland verblijven. Rapportage schattingen 2009 en 2010. Utrecht: Universiteit Utrecht.

Jasso, G. en M.R. Rozenzweig (1990) The New Chosen People: Immigrants in the United States. New York: Russell Sage Foundation.

Kooistra, J.P., W. Ultee en B. Pelzer (2008) Aap, Noot, Mustafa... Het effect van taalafstand en koloniaal verleden op leesprestaties. Mens \& Maatschappij, 83: 258-278.

Laan Bouma-Doff, W. van der (2005) De buurt als belemmering? Assen: Van Gorcum.

Lubbers, M. en M. Gijsberts (2013) Een vergelijking van de arbeidsmarktpositie van Polen en Bulgaren voor en na migratie naar Nederland. Mens \& Maatschappij, 88: 426-446.

Phinney, J.S. (2001) Psychology of ethnic identity. In: N.J. Smelser en P.B. Baltes (red.) International Encyclopedia of the Social and Behavioral Sciences, Vol. 7. Oxford: Elsevier, 4821-4824.

Slik, F. van der (2009) De invloed van de moedertaal op de verwerving van het Nederlands: een onderzoek naar 13 West-Europese eerste talen. Mens \& Maatschappij, 84: 152-176.

Snel, E., M. Faber en G. Engbersen (2013) De maatschappelijke positie van Midden- en Oost-Europese arbeidsmigranten. Justitiële Verkenningen, 6: 61-76.

Tolsma, J., M. Lubbers en M. Gijsberts (2012) Education and Cultural Integration among Ethnic Minorities and Natives in The Netherlands: A Test of the Integration Paradox. Journal of Ethnic and Migration Studies, 38: 793-813.

Tubergen, F. van en M. Kalmijn (2002) Tweede-taalverwerving en taalgebruik onder Turkse en Marokkaanse immigranten in Nederland: investering of gelegenheid? Migrantenstudies, 3: 156-177.

Tubergen, F. van en M. Kalmijn (2005) Destination-Language Proficiency in Cross-National Perspective: A Study of Immigrant Groups in Nine Western Countries. American Journal of Sociology, 110: 1412-1457. 
Tubergen, F. van en M. Kalmijn (2009) Language proficiency and usage among immigrants in the Netherlands: Incentives or opportunities? European Sociological Review, 25: 169-182.

Vervoort, M. (2011) Living together apart? Ethnic concentration in the neighbourhood and ethnic minorities' social contacts and language practices. Den Haag (proefschrift).

Weltevrede, A.M., J. de Boom, S. Rezai, L. Zuijderwijk en G. Engbersen (2009) Arbeidsmigranten uit Midden- en Oost-Europa: Een profielschets van recente arbeidsmigranten uit de MOE-landen. Rotterdam: Risbo BV.

Wobma, E. en R. van der Vliet (2011) Aantal Midden- en Oost-Europeanen in vijf jaar tijd verdubbeld. CBS Webmagazine, maandag 25 juli. 
Bijlage $1 \quad$ Veldwerk onder Poolse, Bulgaarse, Turkse en Marokkaanse respondenten in het SCIP survey

\begin{tabular}{|c|c|c|c|c|}
\hline & Polen & Bulgaren & Turken & Marokkanen \\
\hline $\begin{array}{l}\text { Populatie (aantal migranten in de periode inge- } \\
\text { schreven in Nederland, tussen de } 18 \text { en 65) }\end{array}$ & 12355 & 3226 & 3955 & 1929 \\
\hline Aantal gemeenten & 102 & 16 & 29 & 15 \\
\hline Bruto steekproef & $\begin{array}{l}4705 \\
(38,1)\end{array}$ & $\begin{array}{l}3097 \\
(96,0)\end{array}$ & $\begin{array}{l}2796 \\
(70,7)\end{array}$ & $\begin{array}{l}1812 \\
(93,9)\end{array}$ \\
\hline $\begin{array}{l}\text { Aantal gemeenten geselecteerd voor het onder- } \\
\text { zoek }\end{array}$ & 38 & 16 & 29 & 15 \\
\hline Aselecte steekproef van benaderde respondenten & 2493 & 1585 & 1475 & 1650 \\
\hline $\begin{array}{l}\text { Respondent geeft aan de deur aan al langer in NL } \\
\text { te zijn }\end{array}$ & 8 & 7 & 6 & 71 \\
\hline Ziek/overleden/in een instelling & 2 & I & 2 & 3 \\
\hline Taalproblemen & 1 & 0 & 2 & 0 \\
\hline $\begin{array}{l}\text { Adres onjuist / respondent woont niet (meer) op } \\
\text { het adres }\end{array}$ & $\begin{array}{l}795 \\
(31,9)\end{array}$ & $\begin{array}{l}588 \\
(37,1)\end{array}$ & $\begin{array}{l}224 \\
(15,2)\end{array}$ & $\begin{array}{l}401 \\
(24,3)\end{array}$ \\
\hline Netto steekproef & 1687 & 989 & $|24|$ & 1175 \\
\hline Respondent 6 maal niet thuis & $\begin{array}{l}556 \\
(33,0)\end{array}$ & $\begin{array}{l}425 \\
(43,0)\end{array}$ & $\begin{array}{l}323 \\
(26,0)\end{array}$ & $\begin{array}{l}510 \\
(43,4)\end{array}$ \\
\hline $\begin{array}{l}\text { Migrant niet beschikbaar in de periode / contact } \\
\text { mislukt }\end{array}$ & $\begin{array}{l}28 \\
(1,7)\end{array}$ & $\begin{array}{l}6 \\
(0,6)\end{array}$ & $\begin{array}{l}9 \\
(0,7)\end{array}$ & $\begin{array}{l}9 \\
(0,8)\end{array}$ \\
\hline Bereikte groep & $\begin{array}{l}1103 \\
(65,4)\end{array}$ & $\begin{array}{l}558 \\
(56,4)\end{array}$ & $\begin{array}{l}909 \\
(73,2)\end{array}$ & $\begin{array}{l}656 \\
(55,8)\end{array}$ \\
\hline Weigering & $\begin{array}{l}174 \\
(15,8)\end{array}$ & $\begin{array}{l}78 \\
(14,0)\end{array}$ & $\begin{array}{l}78 \\
(8,9)\end{array}$ & $\begin{array}{l}214 \\
(32,6)\end{array}$ \\
\hline $\begin{array}{l}\text { Andere reden voor non-respons (inclusief afbre- } \\
\text { king van het interview) }\end{array}$ & $\begin{array}{l}55 \\
(5,0)\end{array}$ & $\begin{array}{l}24 \\
(4,3)\end{array}$ & $\begin{array}{l}1 \\
(0,1)\end{array}$ & $\begin{array}{l}12 \\
(1,8)\end{array}$ \\
\hline Gerealiseerde interviews SCIP-NL & $\begin{array}{l}874 \\
(79,2)\end{array}$ & $\begin{array}{l}456 \\
(81,7)\end{array}$ & $\begin{array}{l}830 \\
(91,3)\end{array}$ & $\begin{array}{l}430 \\
(65,5)\end{array}$ \\
\hline Netto respons $=\%$ bereikt $\times \%$ gerealiseerd & $51,8 \%$ & $46,1 \%$ & $66,8 \%$ & $36,5 \%$ \\
\hline
\end{tabular}

